\author{
SONIA HAMMAMI ${ }^{\mathrm{a}, \mathrm{b}}-$ OLFA EZZINE $^{\mathrm{c}}-$ SAMIR DHAHRI $^{\mathrm{b}}-$ CLAIRE VILLEMANT $^{\mathrm{d}}-$ STEFAN SCHMIDT $^{\mathrm{e}}$ \\ MOHAMED LAHBIB BEN JAMÂA ${ }^{\mathrm{b}}$
}

\title{
PUPA MORTALITY OF ORGYIA TRIGOTEPHRAS BOISDUVAL, 1829 (EREBIDAE LYMANTRIINAE) IN TUNISIA
}

\author{
${ }^{a}$ University of Carthage, Faculty of Sciences of Bizerte 7021 (Zarzouna) Bizerte Tunisia \\ ${ }^{\mathrm{b}}$ University of Carthage, National Institute of Research in Rural Engineering, Waters and Forests- LRIIINRGREF01 \\ Laboratory of Management and Valorization of Forest Resources -BP. 10, 2080 Ariana, Tunisia \\ ${ }^{\mathrm{c}}$ University of Carthage, National Institute of Research in Rural Engineering, Waters and Forests- LR161INRGREF03 \\ Laboratory of Forest Ecology -BP. 10, 2080 Ariana, Tunisia \\ 'Institut Systématique Evolution Biodiversité (ISYEB), Muséum national d'Histoire naturelle, CNRS, Sorbonne \\ Université, EPHE, 57 rue Cuvier, CP 50, 75005 Paris, France. \\ e SNSB-Zoologische Staatssammlung München (ZSM), Münchhausenstr. 21, 81247 Munich, Germany \\ Corresponding Author: Sonia Hammami; sonia.hamamii@gmail.com,
}

Hammami S., Ezzine O., Dhahri S., Villemant C., Schmidt S., Ben Jamâa M.L. - Pupa mortality of Orgyia trigotephras Boisduval, 1829 (Erebidae Lymantriinae) in Tunisia.

Orgyia trigotephras (Boisduval) is a polyphagous moth which is bivoltine in Tunisia, with two generations (spring and autumnal). This work, carried out in northeastern and northwestern Tunisia, aimed at studying pupal mortality of this pest on two host species, Quercus coccifera L. and Pistacia lentiscus L. Two types of antagonist factors were assessed: natural mortality (dried pupae) and mortality caused by parasitoids. Three pupal parasitoids species belonging to Hymenoptera order were identified: Brachymeria tibialis (Walker), Pimpla rufipes (Miller) and Monodontomerus minor (Ratzeburg).

Key Words: Orgyia trigotephras, Quercus coccifera, Pistacia lentiscus, Parasitoids, Tunisia.

\section{INTRODUCTION}

Populations of forest pests often fluctuate, showing outbreaks and extended periods of low and endemic densities (BERRYMAN et al., 1987). Phytophagous insects may select plants or plant parts not only based upon nutritional content, but also on the intensity of predation and parasitism they may undergo (BERNAYs et al., 1988). During outbreaks, Lepidoptera defoliators of Quercus trees cause considerable damage, often leading to complete defoliation of trees. This defoliation could cause negative effects on their production and regeneration. Dynamic of lepidopteran insects is limited by the effect of the quality and the quantity of foliage of the host plant (SCHULTZ \& BALDWIN, 1982; FraVAL, 1984; MATTSON \& HAACK, 1987), favorable climate (MARTINAT, 1987) and parasitoids (CANDAU, 2008) which are generally considered as key natural enemies (KIDD \& JERVIS, 1997). These parasitoids have an important place in the ecosystems notably as naturals control agents of herbivorous insects (GODFRAY, 1994).

Orgyia trigotephras is a polyphagous moth widely distributed across the Mediterranean Basin (BASRI, 1994). It feeds on plants of the genus Quercus: Q. suber L., Q. ilex L. (Villemant \& Fraval, 1993; Chakali et al., 2002) and $Q$. coccifera L. (EzzINE et al., 2010), but also on shrub species, mainly: Pistacia lentiscus L. (EzzINE et al., 2010; BELLA et al., 2011) and Retama monosperma L. (Dionisio, 2002).

Populations of oak lepidopteran pests are regulated by a variety of parasitoids that attacks every of their preimaginal instars (VILlemant \& Fraval, 1991). In Morocco, in the Mamora cork oak forest, VILLEMANT (1989) reported the presence of five species of Hymenoptera parasitizing
Lymantria dispar pupae: The Ichneumonidae Pimpla rufipes (F.), P. turionellae moraguesi (Schmiedecknecht) and Vulgichneumon sp., as well as two species of Chalcidoidea: the Chalcididae Brachymeria tibialis (Walker) and the Torymidae Monodontomerus aereus (Walker). Among them $P$. turionellae moraguesi and $M$. aereus were also reported as parasitoïds of $O$. trigotephras in the same forest (Villemant \& FraVAl, 1991). BASRI (1994) also reported that $P$. turionellae moraguesi and $P$. rufipes attack both moth species in Morocco.

In a previous work (HAMMAMI et al., 2017) we showed that larval mortality of $O$. trigotephras in Tunisian oak forests has a significant impact on its population dynamics. In the present work, we combined field data and laboratory experiments, to evaluate the factors inducing pupal mortality of this pest: (i) dried pupae and (ii) mortality due to pupal parasitoids.

\section{MATERIALS AND METHODS}

STUdy AREA

The study was carried out in the northeastern (Jebel Abderrahmane, Cap Bon) in (Ftahiz; alt. $121 \mathrm{~m}, 36^{\circ} 52^{\prime} \mathrm{N}$, $\left.10^{\circ} 45^{\prime} \mathrm{E}\right)$, (Delhiza; alt. $401 \mathrm{~m}, 36^{\circ} 51^{\prime} \mathrm{N}, 10^{\circ} 47^{\prime} \mathrm{E}$ ) and (Guitoun; alt. $136 \mathrm{~m}, 36^{\circ} 83^{\prime} \mathrm{N}, 10^{\circ} 82^{\prime} \mathrm{E}$ ) and the northwestern (Sejnane, Bizerte) (Dam Ziatine, alt. $48 \mathrm{~m}$, $\left.37^{\circ} 11^{\prime} \mathrm{N}, 9^{\circ} 11^{\prime} \mathrm{E}\right)$ Tunisia.

SAMPLING AND HOST PLANT INFESTATION LEVEL

Pupae collection was made in 2013 from mid-May to mid-June, on 30 trees of each plant species: Q. coccifera 
(QC) and P. lentiscus (PL) in every station (Table 1). As a whole, 221 pupae were directly collected from the field. All were then placed individually in plastic boxes $(8 \mathrm{~cm}$ height $\mathrm{x} 3 \mathrm{~cm} \mathrm{Ø)} \mathrm{at} 25 \pm 2^{\circ} \mathrm{C}$ to follow mortality factors (dried pupae) and parasitism (parasitoid's emergence) (Table 1).

After two years of outbreak, in 2005 and 2009 (EZZINE et al., 2015a), the pest remained at low level of infestation in Jebel Abderrahmane since 2012 (EzzINE, 2016). In Sejnane, the pest population remained at low level since it has been first recorded in 2010 inducing with the Gelechiidae Anacampsis scintillella the defoliation of trees and shrubs (including QC and PL) of this cork oak forest (EzzINE et al., 2015b). In this work, host plant infestation was evaluated by counting the number of moth pupae on 30 trees of each plant species.

Table 1 - Number of pupae $(\mathrm{N})$ collected from each station and on host plant species.

\begin{tabular}{|c|c|c|}
\hline \hline \multirow{2}{*}{ Station } & Host plant & $\mathrm{N}$ \\
\hline \multirow{2}{*}{ Ftahiz } & P. lentiscus & 68 \\
\hline \multirow{2}{*}{ Delhiza } & Q. coccifera & 7 \\
\cline { 2 - 3 } & P. lentiscus & 50 \\
\cline { 2 - 3 } Guitoun & Q. coccifera & 38 \\
\cline { 2 - 3 } & P. lentiscus & 26 \\
\hline \multirow{2}{*}{ Dam Ziatine } & Q. coccifera & 7 \\
\cline { 2 - 3 } & P. lentiscus & 8 \\
\hline & Q. coccifera & 17 \\
\hline
\end{tabular}

\section{PARASITOID IDENTIFICATION}

Emerged adults of parasitoids were preserved with ethanol (96\%) in Eppendorf tubes (1.5 ml). Morphological identification was done at species level using keys: BOUČEK (1951) for Brachymeria tibialis, FITTON et al. (1988) for Pimpla rufipes and PECK et al. (1964) for Monodontomerus minor.

\section{STATISTICAL ANALYSIS}

Generalized linear models (GLMs) were applied to the following dependent variables: (1) number of pupae on each host species; (2) total dead pupae; (3) dried pupae and (4) parasitized pupae. Two explanatory categorical variables were tested: host species and stations. The best distribution model was chosen according to the deviance to the degrees of freedom (df) criterion. A Poisson distribution model best fitted the number of pupae on each host species and total of $M$. minor in each station. For the other variables, the Negative Binomial distribution model best fitted the data. Results are presented in the form of the Wald's chi-square test value $\left(\chi^{2}\right)$, parameter estimates and the respective $\mathrm{P}$ value.

\section{RESULTS}

HoST PLANT INFESTATION LEVEL

There is a significant difference of infestation level (mean number of pupae/tree) between the two host plants $\left(\chi_{1}^{2}=4.613 ; P=0.032\right)$ but not between stations. The interaction term was significant $\left(\chi_{2}^{2}=7.623 ; P=0.022\right)$. Number of pupae observed on PL was the highest in Ftahiz and the lowest in Dam Ziatine (Table 2) while, on QC the number of observed pupae was the highest in Delhiza and the lowest in Ftahiz and Guitoun (Table 2).
Table 2 - Average number $( \pm \mathrm{SE})$ of pupae in each station on both host plant species.

\begin{tabular}{|c|c|c|c|c|c|}
\hline \hline \multirow{3}{*}{ Station } & \multirow{2}{*}{ Host plant } & \multicolumn{4}{|c|}{ Number of pupae } \\
\cline { 3 - 6 } & $\begin{array}{c}\text { mean/ } \\
\text { tree }\end{array}$ & SE & $\begin{array}{c}\text { min/ } \\
\text { tree }\end{array}$ & $\begin{array}{c}\text { max/ } \\
\text { tree }\end{array}$ \\
\hline \multirow{3}{*}{ Ftahiz } & P. lentiscus & 2.26 & 0.67 & 2 & 12 \\
\cline { 2 - 6 } & Q. coccifera & 0.23 & 0.1 & 1 & 2 \\
\hline \multirow{3}{*}{ Delhiza } & P. lentiscus & 1.66 & 0.48 & 2 & 10 \\
\cline { 2 - 6 } & Q. coccifera & 1.26 & 0.47 & 1 & 13 \\
\hline \multirow{3}{*}{ Guitoun } & P. lentiscus & 0.86 & 0.37 & 1 & 10 \\
\cline { 2 - 6 } & Q. coccifera & 0.23 & 0.12 & 1 & 3 \\
\hline \multirow{2}{*}{$\begin{array}{c}\text { Dam } \\
\text { Ziatine }\end{array}$} & P. lentiscus & 0.80 & 0.29 & 1 & 5 \\
\cline { 2 - 6 } & Q. coccifera & 1.1 & 0.3 & 1 & 6 \\
\hline
\end{tabular}

\section{GENERAL PUPAL MORTALITY}

Among the 221 studied pupae, 165 adult moths emerged (74.6\%). Pupal mortality was $25.3 \%$ as a whole. There was no significant difference between stations and host plants. In Ftahiz (42\%) and Dam Ziatine (23\%) general mortality rate was higher on QC (42\% and $23 \%$ respectively) than on PL ( $26 \%$ and $13 \%$ respectively). Contrariwise, in Delhiza, mortality rate was higher on PL $(38 \%)$ than on QC (16\%). In Guitoun, mortality reached $15 \%$ on both host plants (Fig. I).

\section{DRIED PUPAE}

Statistical analysis showed that there is no significant difference of dried pupae between stations and host plants. In Ftahiz, dried pupae were observed only on PL (10\%), while, in Delhiza and Dam Ziatine dried pupae were observed only on QC (24\% and $16 \%$ respectively) (Fig. II). In Guitoun, percentage of dried pupae varied between $11 \%$ and $14 \%$ on both host plants.

\section{PARASITISM}

Parasitoid adults emerged from June 2013 to September 2013. No significant difference of parasitized pupae numbers was observed between host plants, but a highly significant difference was observed between stations $\left(\chi_{3}^{2}=14.654, P=0.002\right)$. Parasitism was higher on QC in Ftahiz (43\%) and Delhiza on PL (38\%), whereas it

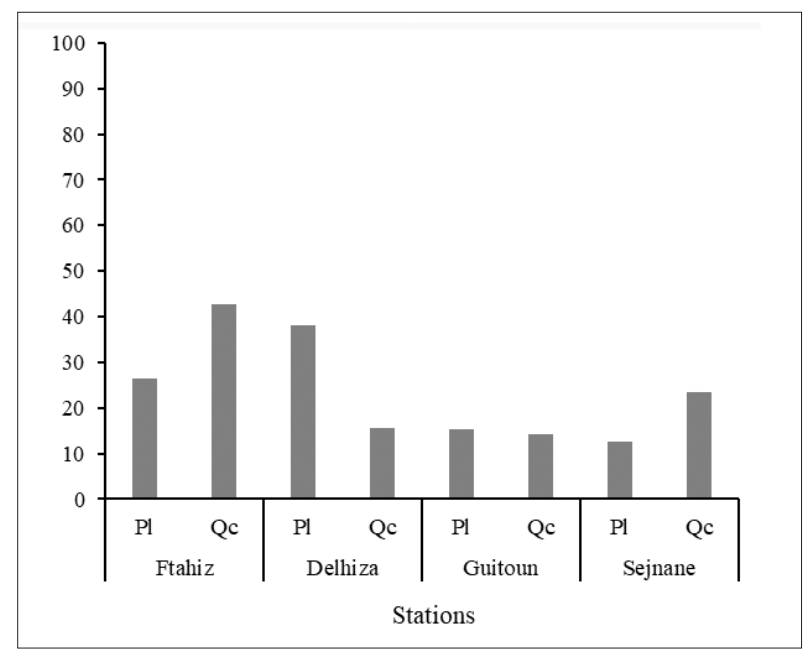

Fig. I - Global mortality rate of $O$. trigotephras pupae on $P$. lentiscus and Q. coccifera. 
remained very low in Guitoun and Dam Ziatine (4\% and $13 \%$ respectively) (Fig. II).

Three pupal parasitoid species belonging to the Hymenoptera order were identified (Fig. III): Brachymeria tibialis (Walker, 1834), Pimpla rufipes (Miller) and Monodontomerus minor (Ratzeburg).

Only one specimen of B. tibialis emerged in July 2013 from pupae collected on PL in Delhiza, also only one specimen of $P$. rufipes emerged from pupae collected on PL in Guitoun in June 2013 and, another one emerged from a pupa collected in Dam Ziatine in July 2013.

Monodontomerus minor was obtained from pupae collected on PL in both Delhiza and Ftahiz, without a significant difference of parasitism. Total number of $M$. minor reached 31 specimens in Delhiza and 10 in Ftahiz. Sex ratio was in favor of females in the two stations reaching 0.40 in Delhiza and 0.25 in Ftahiz.

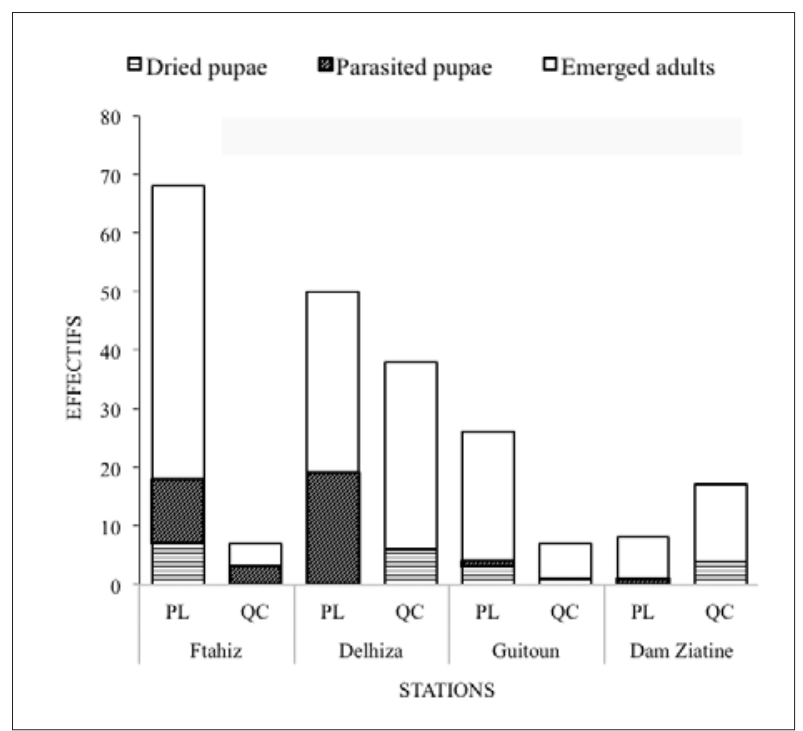

Fig. II - Rate of Parasitism and dried pupae of O. trigotephras on $P$. lentiscus and $Q$. coccifera in each stations.

\section{DISCUSSION}

In our study, as a whole, population density of $O$. trigotephras was low (average density $=1.05$ pupae/tree) and pupa mortality rather low $(25 \%)$. We found that, except for Dam Ziatine (Sejnane) where the general infestation was the lowest, the number of pupae of $O$. trigotephras was higher on PL than on QC (Jbel Abderrhamane). EzzINE et al., (2015a) showed that during outbreak years (2005 and 2009) in Jebel Abderrahmane, density of egg masses of $O$. trigotephras was higher on PL than on QC, while, at low population density (2014), infestation on QC was slightly higher than on PL. EzZINE et al., (2015b) showed that in Sejnane and, during the 2010 outbreak, pupae of $O$. trigotephras were mainly observed on Halimium halimifolium (L.) Willk., $Q$. coccifera and P. lentiscus. However, larval parasitism was also higher on QC than on PL (HAMMAMI et al., 2017) which can partly explain the inverse results we obtained for pupal numbers.

Host use for oviposition by $O$. trigotephras is ruled by resources exploitation in function of density dependent intraspecific competition (EzzINE et al., 2015a) and interspecific competition between $O$. trigotephras and Acrobasis consociella (Pyralidae) which also feed on QC (EzzINE et al., 2016). Our study (2013) coincides with the retrogradation phase of $O$. trigotephras population in all stations. The general mortality varied between stations but not significantly and was higher on PL than on QC in Delhiza. This variability may be due not only to the difference in the density of QC trees that was higher in Delhiza than in the other stations (EzzINE, 2016) but also to the effect of larval parasitoids (HАMмAMI et al., 2017).

Natural mortality (dried pupae) rate may be determined by the pest gradation level, the quantity and the quality of available food that mature larvae need to pupate. Likewise, competition between $O$. trigotephras and $A$. consociella was higher in Delhiza than in the other stations (Ezzine, pers. obs.) since neonate larvae feed on QC (EzZINE et al., 2015a).

FRAVAL (1984) showed that the quality and the quantity
Fig. III - A. Pimpla rufipes: A1. Adult, A2. parazited pupa. B. Brachymeria tibialis: BI. Adult, B2. parazited pupa. CI. Parasitized pupa of M. minor, D1. Adult male of M. minor, D2. adult female of M. minor.

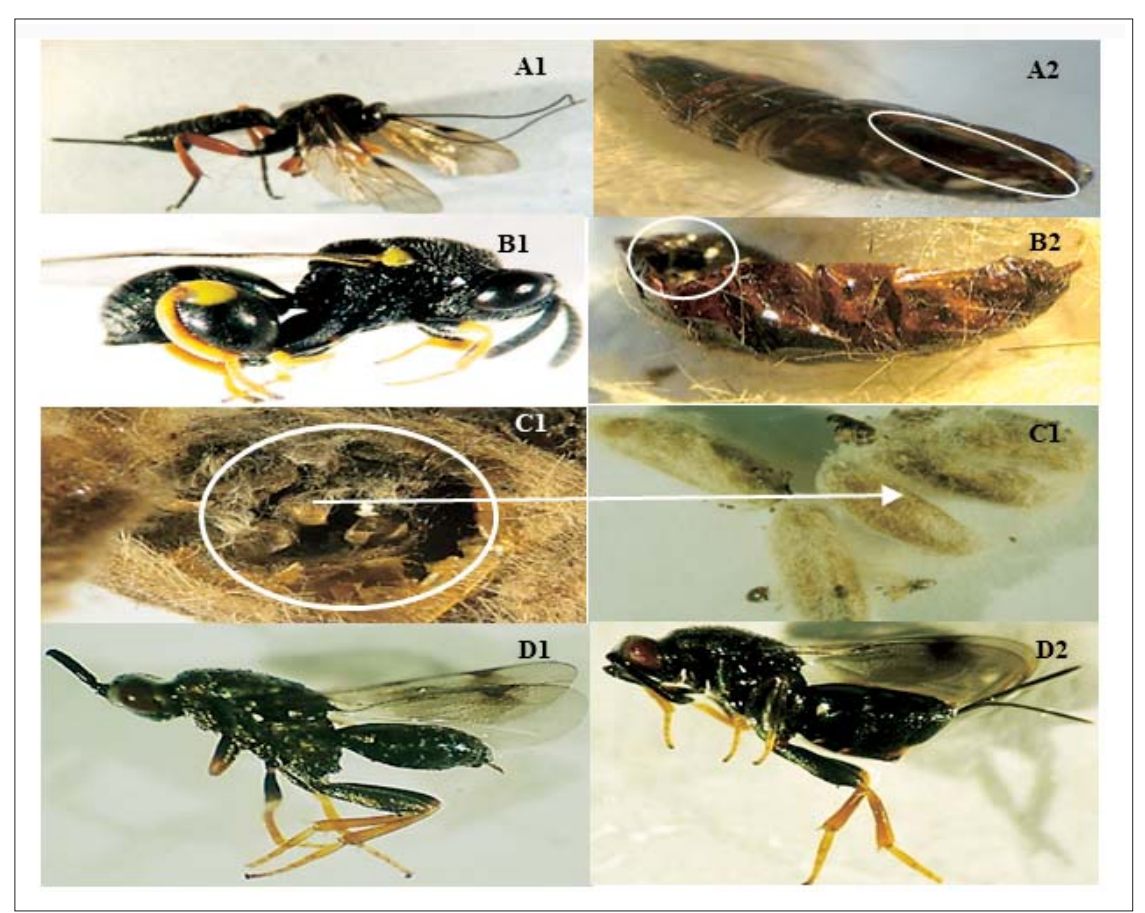


of food are among the most important factors in the regulation of $L$. dispar populations. HÉRARD (1984) showed that the old leaves of cork oak that persist are scorned as long as the new foliage is not exhausted, their consumption by the larvae of $L$. dispar causes high mortality and reduces the reproductive potential of the population.

General mortality caused by parasitism was low (5\%). The pupal parasitism rate was significantly different between host species but not between stations. This may be due to the interaction between plant species. In fact, GRIPENBERG et al. (2010) showed that host plant selection and herbivore performance are correlated. Furthermore, ConNell (1983) indicated that competition among different plant species includes all the limiting effects between plants (resources and allopathy) which reduce or prevent the growth and the survival of the plant.

Thus, the use of plants like PL that do not offer good food quality can be offset by an indirect positive effect "the escape from natural enemies" (EzzINE et al., 2015a). It should be the case of $M$. minor that was observed only on PL in Jebel Abderrahmane. Forty-one specimens emerged in the lab from pupae collected on PL from early June to the end of September 2013. This Torymidae is a gregarious parasitoid of lepidopteran pupae and often a hyperparasitoid of Hymenoptera and Diptera via their lepidopteran and Hymenopteran hosts (STEFFAN, 1952; KULMAN, 1965; IWATA \& TACHIKAWA, 1966).

The other parasitoids collected are too few to draw the same hypothesis. Only one specimen of B. tibialis was observed on PL in only one station (Delhiza) where it was already observed during an outbreak of $O$. trigotephras in 2005 (Ezzine pers. obs.). Brachymeria tibialis is known to attack L. dispar during outbreak (VILLEMANT, 1989) in most European and North African countries.

Another common parasitoid of moths in Europe, $P$. rufipes, attacks a wide range of Lepidoptera species (VIllemant \& FraVal, 1991), notably pupae of $L$. dispar and O. trigotephras (DAJOz, 2010). In our study (2013) two specimens of this ichneumonid emerged from pupae collected on PL in Guitoun and Dam Ziatine, while in 2009, it was observed on QC in December in Delhiza and in June in Dam Ziatine (Ezzine pers. observ.).

These results highlight the complexity of mechanisms of pupa mortality involving the relation between their host plant use and parasitoids (higher trophic level) and the difficulty to highlight them at low pest population densities. The assembly of parasitoids in a particular habitat depends indeed on host and environmental factors and may result in different degrees of natural control of a given pest (MILLS, 1994).

\section{REFERENCES}

Aubert J.F., 1967 - Supplément à la révision des Ichneumonidés Scambus HTG. Ouest paléarctiques. Bulletin de la société entomologique Suisse, 3 : 907-920.

BASRI E., 1994 - Orgyia trigotephras BOISD (lepidoptera, Lymantridae). In : El Hassani A., Graf P., Hamdoui M., Harrachi K., Messaoudi J., Mzibri M. et Stiki A, Ravageurs et maladies des forêts au Maroc (guide pratique pour la protection phytosanitaire des forêts). Editions D.P.V.C.T.R.F., Rabat, pp 99-101.

BernaYs E.A., GRAHAM M., 1988 - On the evolution of host specificity in phytophagous arthropods. - Ecology, 69 (4): 886-892.
Berryman A.A., Stenseth N.C., Isaev A.S., 1987 Natural regulation of herbivorous forest insect populations. - Oecologia, 71: 174-184.

BOUČEK Z., 1951 -The first revision of the European species if the family Chalcididae (Hymenoptera). - Acta entomologica musei nationalis Pragae XXVII, supplementum, 1:1- 108 .

CANDAU J.N., 2008 - Impacts du changement climatique sur les insectes ravageurs des forêts méditerranéennes. Forêt méditerranéenne, XXIX, 2 : 145-154.

Chakali G., Attal-Bedreddine A., OuZani H., 2002 - Les insectes ravageurs des chênes, Quercus suber et Quercus ilex, en Algérie. - IOBC / WPRS Bulletin, 25 (5): 93-100.

ConNell J.H., 1983 - On the prevalence and relative importance of interspecific competition: evidence from field experiments. - American Naturalist, 12: 661-696.

DAJOZ R., 2010 - Dictionnaire d'entomologie : Anatomie, Systématique, Biologie. Edition TEC et DOC 11, 330 pp.

Dionisio M.H., 2002 - Lepidópteros de Huelva (I). Especies detectadas en las márgenes del río Guadiana. - Boletín de la Sociedad Andaluza de Entomología, 4: 9-29.

DGF, Direction Generale Des Forets., 1995 - Forêt domaniale De Béni Oulid. Plan d'aménagement 19962015. SOGET Maghreb, 89 p+cartes+annexes.

DGF, Direction Generale Des Forets., 1996 - Etude de l'impact sur l'environnement du projet d'aménagement hydro-agricole de l'Oued Ziatine (rapport proviso ire). Direction générale des grands travaux hydrauliques, 40 p+annexes.

Bella S., Longo S., Sidoti A., 2011 - Indagini su Teia trigotephras defogliatore del lentisco nella Sicilia sud orientale. - Dissertation, Atti XXIII Congresso Nazionale Italiano di Entomologia.

Ezzine O., Ben JamaA M.L., Mnara S., Nouira S., 2010 Bioécologie d'Orgyia trigotephras (Boisduval, 1829), (Lepidoptera, Lymantriidae) à Jebel Abderrahmane, Cap Bon (Nord Est de la Tunisie). - IOBC/WPRS Bulletin, 57 : 123-127.

Ezzine O., Branco M., Villemant C., Schmidt S., Nouira S., Ben JamÂA M.L., 2015a - Host use in Orgyia trigotephras (Erebidae, Lymantriinae) during outbreak: effects on larval performance and egg predation. - Annals of Forest Science, 72: 561-568.

Ezzine O., Hammami S., Hausmann A., Nouira S., Ben JAMÂA M.L., 2015b - First Report of Anacampsis scintillela on Halimium halimifolium in Sejnane (Bizerte, Tunisia). - Tunisian Journal of Plant Protection, 10 (1): 63-68.

EzZINE O., 2016 - Interactions insectes/plantes- hôtes: cas Orgyia trigotephras Boisduval (1829) (Lepidoptera, Erebidae) en Tunisie - Doctorate Thesis in Biology, Faculté des Sciences Mathématiques, Physiques et Naturelles de Tunis, Université El Manar, Tunisia, 206 pp.

Ezzine O., Hammami S., Dhahri S., Ben JamÂa M.L, 2016 - Contribution to the bio-ecology of Acrobasis consociella (Hübner, 1813) (Pyralidae, Phycitinae) in Tunisia. Turkish Journal of Forestry, 17(Special Issue): 44-47.

Ezzine O., Mhamdi S., Hammami S., Dhahri S., Ben JAMÂA M.L., 2017 - Infestation of Quercus coccifera by Phyllonorycter messaniella (Zeller, 1846) (Lepidoptera, Gracillariidae) in Tunisia. - Bulletin IOBC/wprs., 127: 30-36.

Fitton M.G., Shaw M.R., Gauld, I.D., 1988 - Pimpline Ichneumon-Files: Hymenoptera, Ichneumonidae (Pimplinae). - Royal entomological society of London, 7 (1): 110 . 
Fraval A., 1984 - Influence de la qualité et de la quantité de l'alimentation sur les fluctuations des populations de Lymantria dispar L. (Lep., Lymantriidae) en forêt de la Mamora (Maroc). - Agronomie, 4 (9); 819-828.

Gillott C., 2005 -Entomology, third edition. Springer, Netherlands, $831 \mathrm{pp}$.

Godfray H.C.J., 1994b - Parasitoids: behavioral and evolutionary ecology. - Princeton University Press, Princeton, New Jersy, 473pp.

Gripenberg S., Mayhew P.J., Parnell M., Roslin T., 2010 - A meta-analysis of preference performance relationships in phytophagous insects. - Ecology Letters, 13 : 383-393.

Hammami S., Ezzine O., Dhahri S., Villemant C., Schmidt S., BEN JAMÂA. M.L., 2017 - Importance of parasitoids of Orgyia trigotephras caterpillar's Boisduval, 1829 (Erebidae, Lymantriinae) in Tunisia. - Bulletin IOBC/wprs., 127: 37-44.

HÉRARD F., 1984 - Étude des relations trophiques entre Lymantria dispar L. (Lépidoptère, Lymantriidae) et Quercus suber (L.) dans les conditions simulées en laboratoire de la forêt de la Mamora (Maroc) 1. Enoncé général des résultats. - Actes Institut. agronomique et vétérinaire du Maroc., 4: 147-155.

Hoch G., Zubrik M., Novotny J., Schopf A., 2001 -The natural enemy complex of the gypsy moth, Lymantria dispar (Lep. Lymantriidae) in different phases of its population dynamics in eastern Austria and Slovakia - a comparative study. - J. Appl. Entomol., 125: 217-227.

IWATA K., TACHIKAWA T., 1966 - Biological observations on 53 species of the superfamilies' Chalcidoidea and Proctotrupoidea from Japan (Hymenoptera: Apocrita). Transactions of the Shikoku Entomological Society, 9:129.

KIDD N.A.C., JERVIS M.A., 1997 - The impact of parasitoids and predators on forest insect populations. In: Watt AD, Stork NE, Hunter MD. (eds): Forests and Insects. Chapman \& Hall, London, pp. 49-68.

MARTINAT P.J., 1987 - The role of climatic variation and weather in forest insect outbreaks. In: Barbosa P. et Schultz J. (eds) Insect outbreaks. Academic Press, New York, pp 241-268.

MATTSON W.J., HAACK R.A., 1987 - The role of drought in outbreaks of plant-eating insects. - Bioscience, 37: 110118.

Mills N.J., 1994 - The structure and complexity of parasitoid communities in relation to biological control. In: Hawkins B.A., Sheehan W., (eds) 397-417. Parasitoid Community Ecology, Oxford University Press, Intercept, Andover.

OHGUSHI T., 1992 - Resource limitation on insect herbivore populations. In: Hunter M.D., Ohgushi T., Price P.W., (eds). Effects of resource distribution on animal-plant interactions. Academic Press Inc, New York, pp. 199-241.

Pschorn-Walcher H., 1977 - Biological Control of forest insects. - Annu. Rev. Entomol, 22: 1-22.

Peck O., Bouček Z., Hoffer A., 1964 - Key to the Chalcidoidea of Czechoslovakia (Insecta: Hymenoptera). - Memoirs of the Entomological society of Canada, 34: 120.

Schultz J.C., BALdwin I.T., 1982 - Oak leaf quality declines in response to defoliation by gypsy moth larvae. Science, 217: 149-151.

STEFFAN J.R., 1952 - Note sur les espèces européennes et nord africaines du genre Monodontomerus Westw. (Hym. Torymidae) et leurs hôtes. - Bulletin du Museum National d'Histoire Naturelle, Paris, (2) 24(3): 288-293.

Villemant C., 1989 - Ennemis des chenilles et des chrysalides. In: Fraval A., Lymantria dispar. - Coll. Doc, Sci.techn. Actes Editions Rabat, pp. 125-143.

Villemant C., 2003 - Le Bombyx disparate en Corse Insectes, 130 (3): 5-10.

Villemant C., Fraval A., 1991 - La faune entomologique du chêne-liège. Actes Editions Rabat.

Villemant C., FraVAl A., 1993 - La faune entomologique du chêne-liège en forêt de la Mamora (Maroc). Ecologia Mediterranea, 19 (4): 89-98. 
112 - Blank Page 